\title{
Physical and gas permeation properties of five-layer polyethylene film used as greenhouse roof
}

\author{
Abdelkader Dehbi, ${ }^{1}$ Boulos Youssef, ${ }^{2}$ Abdel-Hamid I. Mourad, ${ }^{3}$ Corinne Chappey, ${ }^{2}$ Pietro Picuno, ${ }^{4}$ Dina Statuto ${ }^{4}$ \\ ${ }^{1}$ Laboratoire de Génie Physique, Université d'Ibn Khaldoun, Tiaret, Algérie; ${ }^{2}$ Normandie Univ, INSA Rouen, Univ \\ Rouen, CNRS, PBS, Rouen, France; ${ }^{3}$ Mechanical Engineering Department, College of Engineering, United Arab \\ Emirates University, Al Ain, UAE; On leave from Mechanical Design Department, Faculty of Engineering, Al Mataria, \\ Helwan University, Egypt; ${ }^{4}$ SAFE School, University of Basilicata, Potenza, Italy
}

\begin{abstract}
The effect of sand wind ageing simulation performed under different conditions for a five-layer film consisting of polyethylene, poly-vinyl-acetate and various additives has been investigated. The mechanical properties of the five-layer films after several treatments were evaluated, together with their surface morphology - analysed by using Fourier transform infrared and contact angle and gas permeation properties. The experimental analysis indicated that these treatments had a significant influence on the surface of the film only. An attempt has been done to compare the properties of the five-layer films with the monolayer and tri-layer films with or without air bubble under similar conditions.
\end{abstract}

\section{Introduction}

Agriculture is the most important sector in which plastic material is employed as a primary building component. Within civil and industrial constructions - where other building materials (i.e., bricks, concrete, steel, wood, etc.) are more widespread - the use of this material is limited to complementary applications, as window or door frames, flooring or facing covers, insulation or waterproofing material, rain water goods, etc.. Employed as a covering material to protect cultivation, plastic plays indeed a central role, by performing a passive effect - protecting crops from negative weather conditions, dust, animals, birds, insects, etc. - and, at the

Correspondence: Dina Statuto, School of Agriculture, Forestry, Food and Environmental Sciences (SAFE), University of Basilicata, viale Ateneo Lucano 10, 85100 Potenza, Italy.

E-mail: dina.statuto@unibas.it

Key words: Greenhouse; five-layer film; sand wind; gas permeability; mechanical behaviour.

Received for publication: 3 October 2017.

Accepted for publication: 27 November 2017.

CC Copyright A. Dehbi et al., 2018

Licensee PAGEPress, Italy

Journal of Agricultural Engineering 2018; XLIX:797

doi:10.4081/jae.2018.797

This article is distributed under the terms of the Creative Commons Attribution Noncommercial License (by-nc 4.0) which permits any noncommercial use, distribution, and reproduction in any medium, provided the original author(s) and source are credited. same time, an active effect, contributing to the realisation of a more favourable environment for the cultivations (Picuno, 2014).

The growing use of plastics in agriculture has indeed enabled farmers to increase their crop production. The use of plastics in agriculture results in increased yield, earlier harvest, less reliance on herbicides and pesticides, better protection of food products and more efficient water conservation. Crop protection from hail, wind, snow, or strong rainfall in horticulture, together with the realisation of a confined airspace with controlled microclimatic conditions, is the most common case (Statuto and Picuno, 2017). Plastic films are widely diffused for covering greenhouses, low and medium tunnels, and soil mulching (Figure 1). However, this increasing use creates serious environmental problems connected to the change that the agro-ecosystem may suffer at different scales (Statuto et al., 2013), the alteration of the visual quality of agricultural landscape (Statuto et al., 2016) and the need to collect and dispose high quantities of agricultural plastic waste (Picuno et al., 2012).

Low-density polyethylene (LDPE) is one of the main polymers widely used for the greenhouse cover (Briassoulis, 2006, 2007; Dehbi et al., 2015), to maintain favourable conditions of temperature, lighting, gas composition $\left(\mathrm{O}_{2}, \mathrm{CO}_{2}, \mathrm{~N}_{2}\right)$ and humidity for optimal photosynthesis, respiration and growth of the plants. In spite of the low cost of these polymeric materials, the economic advantages of plasticulture can be seriously undermined by extreme climatic factors, which decrease the lifetime of the plastic cover (Dehbi and Mourad, 2011; Mourad and Dehbi, 2014). Despite the continuous efforts made by plastic producers (Schettini et al., 2011), this important characteristic is actually limited in Europe and in the US (four to five seasons) and from two to three seasons in Saharan environment (Dehbi et al., 2012a). The specific climatic conditions, besides the high temperature, such as solar radiation, humidity, mechanical constraints, sand wind etc. can modify considerably some technical properties like mechanical strength, transparency and gas permeability of the exposed plastic films (Fuina et al., 2016). Moreover, these elements promote the degradation of the polymeric material in its environment resulting into an important residual pollution.

Various researchers were interested in the long-term behaviour of these plastic covers. Some studies (Guenachi et al., 2002) analysed the effect of a sand wind simulation on a LDPE monolayer film, keeping it for $4 \mathrm{~h}$ at $40^{\circ} \mathrm{C}$. They showed that this creates on the exposed surface a very weak layer of material inlaid with particles of sand. Dehbi et al. (2012b) reported that the durability of the material depends on its fitness to resist the erosion. In these studies, variations in the structures were analysed using Fourier transform infrared (FTIR), differential scanning calorimetry and mechanical properties.

Earlier, the covers of agricultural greenhouses were made up of monolayer films of LDPE having about 200- $\mu$ m thickness 
$(120-200 \mu \mathrm{m})$. In spite of its quick thermal transmission nature, poor mechanical properties, and short lifetime, tri-layer films (Youssef et al., 2008; Mourad, 2010), typically 220- $\mu$ m thickness made of LDPE, poly-vinyl-acetate (PVA) with air bubbles entrapped in the middle layer were developed (PROSYNPOLYAN). Due to the air bubble in the middle layer, this is more efficient to maintain the temperature in the greenhouse (Dehbi et al., 2017). However, tri-layer films based on LDPE, produced by Agrofilm SA (Algeria) without air bubble show superior mechanical property when compared to the monolayer film. Recently, fivelayers films for greenhouse were proposed by Ginegar Plastic Product Ltd. From the literature survey, to our knowledge, no works were reported so far concerning the gas permeation of multilayer films (Dehbi et al., 2017) used as covering in the agriculture field. In this paper we propose to analyse the properties of the surface and gas permeability $\left(\mathrm{O}_{2}\right.$ and $\left.\mathrm{CO}_{2}\right)$ behaviour of a five-layers film in an Saharan environment i.e. simulation using sand wind for $8 \mathrm{~h}$ at $40^{\circ} \mathrm{C}$, under temperature and temperature/UVA condition for $1000 \mathrm{~h}$ at $40^{\circ} \mathrm{C}$. Since the $\mathrm{O}_{2}$ and $\mathrm{CO}_{2}$ play a significant role for the growth of the plants, it is very important to have a systematic study on the permeability nature of these films. The direct effects of increased carbon dioxide $\left(\mathrm{CO}_{2}\right)$ on plant growth refers to the change in plant grow with the levels of temperature, precipitation, evaporation and growing season at their present values. The indirect effects include the results of any changes in the other variables which affect plant growth that come as a result of the effect of increased $\mathrm{CO}_{2}$ on global climate. Finally the properties of the fivelayer films were compared with the monolayer and tri-layer films with or without air bubbles used in the greenhouse under similar conditions.

\section{Materials and methods}

The material used for this study was supplied by Ginegar Plastic Product Ltd. as a greenhouse cover film called Sun Selector/Suntherm 4. The film is obtained by extrusion and has a thickness of $200 \mathrm{~mm}$. It consists of five layers: two external polyethylene (PE) layers and a central PVA (PVAc) layer with two intermediate layers containing adhesives to ensure the cohesion between $\mathrm{PE}$ and PVAc. This intermediate layers containing adhesives consists of various additives such as anti-condensation, anti-UV, anti-parasite, anti-virus, anti-dust, anti-drops, etc. The real chemical composition of the film was kept confidential by the supplier.

For the ageing tests, the following five-layer films were tested and the 30 Watts lamp being placed $20 \mathrm{~cm}$ away above the samples: i) virgin film; ii) film after artificial sand-wind simulation for $8 \mathrm{~h}$ at $40^{\circ} \mathrm{C}$; iii) film after artificial ageing $1000 \mathrm{~h}$ at $40^{\circ} \mathrm{C}$; iv) film after artificial ageing by UVA (with wavelength range of 315-380 $\mathrm{nm})$ for $1000 \mathrm{~h}$ at $40^{\circ} \mathrm{C}$.

The method used for the artificial sand-wind was described in Dehbi et al. (2012b). This equipment was composed of a thermostatic tube, a sand-wind chamber and a control keyboard. From an air turbine, the flux was heated up to the target experimental temperature $\left(\mathrm{T}=40^{\circ} \mathrm{C}\right)$, under a pressure of $100 \mathrm{kNm}^{-2}$, inside the thermostatic tube. This dry air was introduced in the sand-wind chamber where natural sand particles were deposited. A Brownian movement of the sand particles resulted, randomly striking the polymer surface. The five-layers film was subjected to this treatment during $8 \mathrm{~h}$.

The surfaces of the films tested were examined before and after sand-wind ageing by using a Leica DMLM microscope (Japan).
Fourier transform infrared spectroscopic analysis was recorded in total reflection on a Nicolet Avatar 360 instrument equipped with a germanium crystal. A number of 128 scans were accumulated with a resolution of $4 \mathrm{~cm}^{-1}$ for each spectrum. IR spectra present absorbance from 3000 to $600 \mathrm{~cm}^{-1}$. The calculations were made for the various samples after standardisation, according to a reference peak. The peak at $2920 \mathrm{~cm}^{-1}$ was chosen as reference since it remains identical for all the samples.

The changes in the polymeric surfaces have been checked by determining the free surface energy of the different samples by means of contact angle measurements. Three reference liquids, ultra-pure water (milli-Q WaterSystem, resistivity $18 \Omega / \mathrm{cm}$ ), glycerol and diiodomethane were used. All measurements were carried out at room temperature $\left(23^{\circ} \mathrm{C}\right)$. For each liquid deposited on the sample surface, we made an average of five measurements. A drop of $3 \mathrm{~mL}$, deposited with a micro syringe, was photographed with a black and white $\mathrm{CCD}$ camera $(500 \times 500)$. Contact angle $\theta$ was determined from a computerised contact angle meter (NFT Communications Company, Tours, France).

The tensile tests of films were carried out using a universal testing machine (Instron model 4301, France). The tests were performed using a $5 \mathrm{kN}$ load cell at a crosshead speed of $2 \mathrm{~mm} / \mathrm{min}$. The tensile modulus (E) was obtained from the tangent at the origin of the stress-elongation curve according to the AFNOR NF T54-102. The results obtained represent an average value calculated from five samples.

The gas permeation properties of the films towards oxygen and carbon dioxide were determined by using the time-lag technique based on the variable pressure method (Crank and Park, 1968; Joly et al., 1999), During all experiments, the temperature of the permeation apparatus was kept at $25^{\circ} \mathrm{C}$ in a thermo regulated chamber (Figure 2). Before measurement, the permeation cell (XX45047 Millipore filtration cell adapted for gas permeation) was completely evacuated by applying vacuum $\left(10^{-3} \mathrm{mbar}\right)$ on both sides of the film for at least $10 \mathrm{~h}$ (valves V1 and V3 closed, V2 and V4 open). Then the upstream side was provided with the gas under test at pressure $\mathrm{p}_{1}$ (V2 and V4 closed, V1 open). The increase of pressure $\mathrm{p}_{2}$ in the calibrated downstream volume $\mathrm{V}$ was measured and recorded using a sensitive pressure gauge (0-10 mbar, Effa AW-10T4) linked to a data acquisition system.

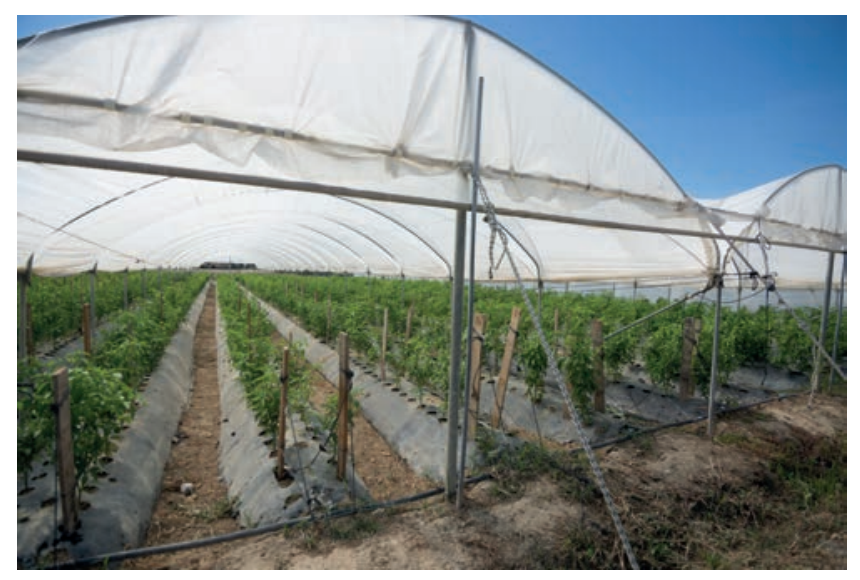

Figure 1. Plastic-covered tunnel with inside plastic soil mulching. 


\section{Results and discussion}

FTIR spectra of the surface of five-layer film kept at different conditions such as after sand wind treatment, keeping at $40^{\circ} \mathrm{C}$ for $1000 \mathrm{~h}$ and $\mathrm{UVA} /$ temperature at $40^{\circ} \mathrm{C}$ for $1000 \mathrm{~h}$ is given in Figure 3. The initial film spectrum (Figure $3 \mathrm{~A}$ ) presents bands, which are characteristic of polyethylene: $\mathrm{CH}_{2}$ stretching vibrations (2920 and $\left.2850 \mathrm{~cm}^{-1}\right), \mathrm{CH}_{2}$ deformation vibrations $\left(1470 \mathrm{~cm}^{-1}\right)$, and $\mathrm{CH}_{2}$ skeleton vibrations $\left(720 \mathrm{~cm}^{-1}\right)$.

During ageing (samples kept at $40^{\circ} \mathrm{C}$ ) we observed that the absorption band at $1470 \mathrm{~cm}^{-1}$ does not vary before $700 \mathrm{~h}$. After that, new peaks appeared between 650 and $1750 \mathrm{~cm}^{-1}$ especially at $1650 \mathrm{~cm}^{-1}, 1390 \mathrm{~cm}^{-1}$ and $1029 \mathrm{~cm}^{-1}$ that correspond to oxygenated groups, and those at $1540 \mathrm{~cm}^{-1}$ and $1450 \mathrm{~cm}^{-1}$ which correspond to absorption band of vibrations of $\mathrm{CH}_{2}-\mathrm{O}$ group (Dilara and Briassoulis, 1998) or $\mathrm{C}=\mathrm{C}$ double bonds. The intensity of the peak increases as a function of time. Figure $3 \mathrm{~B}$ presents the variation of the peak of the sample kept at $40^{\circ} \mathrm{C}$ for $1000 \mathrm{~h}$. Here we noticed a peak at $1740 \mathrm{~cm}^{-1}$, which corresponds to the formation of ester groups (Allen et al., 2000). For the samples under UVA/temperature treatment we observed the same phenomenon, but new peaks appeared between 650 and $1750 \mathrm{~cm}^{-1}$. The intensity of the peak increases more significantly compared to the samples kept at $40^{\circ} \mathrm{C}$. Figure $3 \mathrm{C}$ displays the FTIR for the sample kept at UVA at $40^{\circ} \mathrm{C}$ for $1000 \mathrm{~h}$. The peak at $1740 \mathrm{~cm}^{-1}$ observed for the samples kept at $40^{\circ} \mathrm{C}$ for $1000 \mathrm{~h}$ were not seen here.

After sand-wind simulation for $8 \mathrm{~h}$, the same bands of absorptions appear like that of ageing in temperature, with furthermore a band at $875 \mathrm{~cm}^{-1}$ and $1110 \mathrm{~cm}^{-1}$ (Figure 3D) which corresponds to the vibration of Si groups (Youssef et al., 2008; Dehbi et al., $2012 b$ ). Here also we noticed a peak at $1740 \mathrm{~cm}^{-1}$ which corresponds to the formation of ester groups as observed for the samples kept at $40^{\circ} \mathrm{C}$ for $1000 \mathrm{~h}$. Thus, the various bands of absorptions observed after the various ageing constraints show that the surface of film suffered some chemical modifications such as cross linkage, unsaturation and oxidation. Moreover, the chemical modifications observed for the samples kept at $8 \mathrm{~h}$ of treatment by sandwind at $40^{\circ} \mathrm{C}$ and $1000 \mathrm{~h}$ of ageing at $40^{\circ} \mathrm{C}$ are almost similar. A comparison of the FTIR peaks of sand wind treated tri-layer with that of five layer shows similar peaks, but the intensity of peak is more for the tri-layer film (Dehbi et al., 2017). This indicates that additives in the five-layer film are more suitable to resist to the sand wind.

The variation of peak at $1715 \mathrm{~cm}^{-1}$ which represents the bands of vibrations of the carbonyl groups and the peak at $1550 \mathrm{~cm}^{-1}$ and $1415 \mathrm{~cm}^{-1}$ which corresponds to the presence of $\mathrm{CH}_{2}-\mathrm{O}$ and/or $\mathrm{C}=\mathrm{C}$ functions is due to the breaking and branching of double bonds of the polymeric material under different ageing conditions. Under the action of the light and/or heat, the formation of radicals occurs on the film surface, which leads to the reactions of reticulation of chains, reactions with oxygen in air and reactions of scission of chains (Gulmine et al., 2003). The peak at $1740 \mathrm{~cm}^{-1}$ found for the samples kept at $40^{\circ} \mathrm{C}$ for $1000 \mathrm{~h}$ indicates that the degradation mechanism is different for the UVA/temperature treatment with the former.

The presence of any chemical modifications in the film surface due to the effects of temperature and UVA radiations were studied through the measurements of the free surface energy (surface polarisation energy plus the triple- layer dispersion energy). The method is based on the measurement of the contact angle (significant element to know the physico-chemical interactions at the surface of a film).
Here we calculated the free surface energy by measuring the contact angle (q) according to the Equation 1:

$\gamma=\gamma_{\mathrm{d}}+\gamma_{\mathrm{p}}$

$\gamma_{\mathrm{d}}$ and $\gamma_{\mathrm{p}}$ are the dispersive and non-dispersive components, $\gamma$ is the total surface energy $(\mathrm{MJ} / \mathrm{mq})$. According to the relationship proposed by Owens Went method (Owens and Went, 1969) this surface energy is obtained from the following equation:

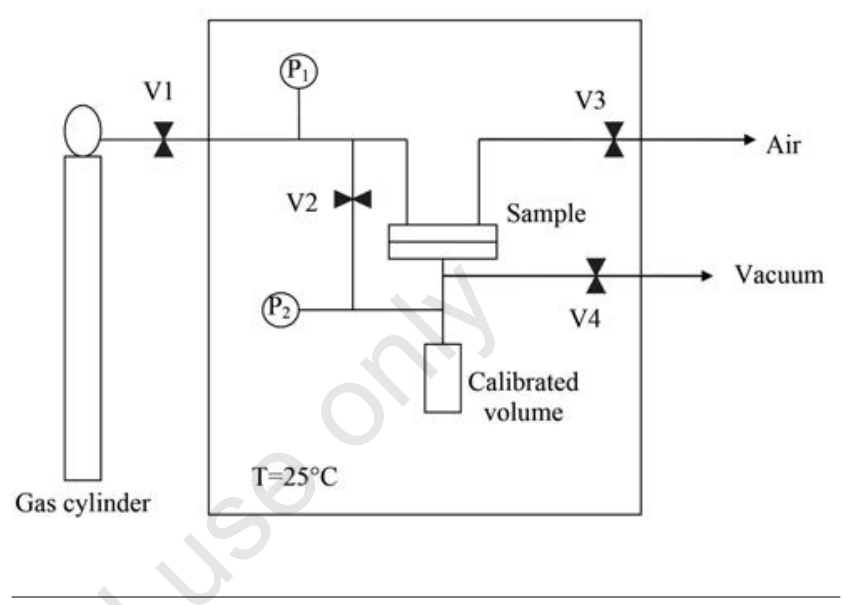

Figure 2. Diagram of the gas permeation apparatus used for the measurement of the $\mathrm{CO}_{2}$ and $\mathrm{O}_{2}$ permeation properties of the films. Vi are gas valves, $\mathrm{p}_{1}$ and $\mathrm{p}_{2}$ are the upstream and downstream pressures.

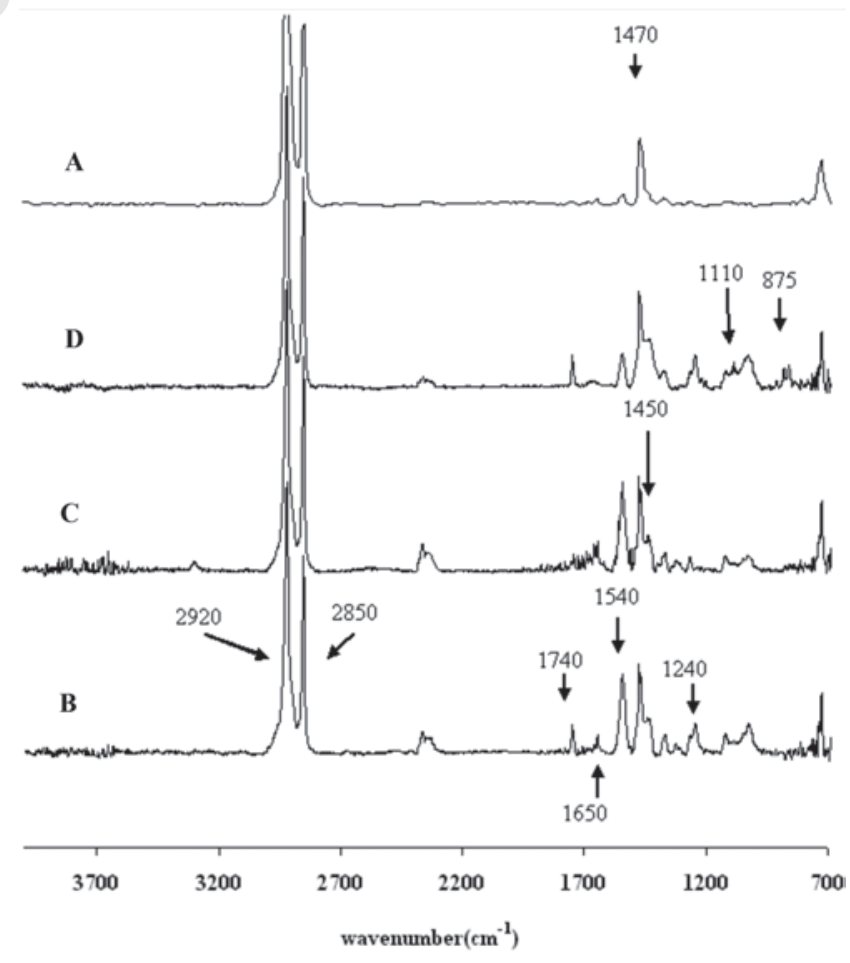

Figure 3. IR spectra of the five-layer film, virgin (A), aged during $8 \mathrm{~h}$ by a sand-wind at $40^{\circ} \mathrm{C}(\mathrm{D})$, aged during $1000 \mathrm{~h}$ at $40^{\circ} \mathrm{C}(\mathrm{B})$ and aged by UVA at $40^{\circ} \mathrm{C}(\mathrm{C})$. 
$\gamma(1+\cos \theta)=2 \sqrt{\gamma_{1}^{d} \gamma_{s}^{d}}+2 \sqrt{\gamma_{1}^{p} \gamma_{s}^{p}}$

where subscripts s and 1 denote the solid and liquid phases respectively. From the comparison of the values of $\gamma, \gamma_{d}$, and $\gamma_{p}$ calculated from the experimental values of q for previously studied monolayer, tri-layer (Youssef et al., 2008) and for the five-layer film (before and after sand-wind treatment), it was possible to conclude that the low values of $\gamma_{p}$ obtained for the different films correspond to polyethylene, which is known to be a non-polar polymer (Joly et al., 1999) and constitutes the external layers of the two multilayer films. These results indicate the appearance of polar groups in consequence of the attack by oxygen and show also an increase of the surface energy $\gamma$ of the films treated by the sand-wind with regard to the initial films. It may be due to the physical modification of the film surface because of the sand wind treatment.

For the first heating of the virgin film, as well as of the aged films, several peaks were observed on after the temperature of $80^{\circ} \mathrm{C}$. A peak is observed at $40^{\circ} \mathrm{C}$ due to the ageing of the samples. This phenomenon is well known for several thermoplastic polymers and can be explained by the fact that during such an annealing, the thermal energy brought is sufficient to authorise rearrangements at the level of crystals with meta-stable structures, even the growth of crystals of small size, which had no time to form during the extrusion of the material (Owens and Went, 1969). Since the existence of a mixture of various range of polyethylene with various degrees of crystallinity has been shown, the calculation of the melting enthalpy $\left(\Delta H_{\text {melting }}\right)$ for all crystalline phase has revealed that there is an apparent change in the values. It appears that whatever the type and time of ageing, the melting enthalpy is almost constant so that, globally, there is no visible change of the crystalline fractions. This is because the ageing is concerned principally on the amorphous phase of the polymeric material. Here the modifications are occurring only on the surface of the polymeric material rather than inner part. The additive in and between the layers prevents the effect of ageing to the core of the material. Similar results were obtained for the ageing of tri-layer polyethylene.

Figure 4 presents the mechanical behaviour curves of the fivelayer and tri-layer film treated by sand-wind at $40^{\circ} \mathrm{C}$. The polyethylene is considered as a hard and firm polymer. We can see that the stress at failure of the aged film is obtained at a higher constraint and with a weaker deformation with regard to the initial film. This phenomenon can be attributed to the cross-linkage, a chemical reaction induced by sand wind and temperature leading to the formation of covalent bridges between the nearby segments of a polymer chain. Considering the mechanical properties, this process usually leads to an increase of the Young modulus and some constraint in the break. So, we can deduce that there was an effective cross-linkage for the films after treatment by sand-wind at $40^{\circ} \mathrm{C}$. For comparison the values of the elastic modulus and percentage of elongation of the mono, tri- (Dilara and Briassoulis, 1998; Youssef et al., 2008) and five-layer films before and after the sand wind treatment are shown in Table 1. After the sand wind treatment, a slight increase of the elastic modulus and decrease of the elongation at break occur for the samples. With regard to the monolayer film, the multi-layer films have higher elastic modulus certainly due to the presence of PVAc as central layer. The elongation at break is higher for the fivelayer than for the three-layer and monolayer films. The five-layer material is thus more resistant than the three-layer and monolayer films, even after exposure to a sand-wind.

Figure 5 shows the time-lag permeation curves of carbon dioxide and oxygen at $25^{\circ} \mathrm{C}$ through the virgin and sand-wind aged

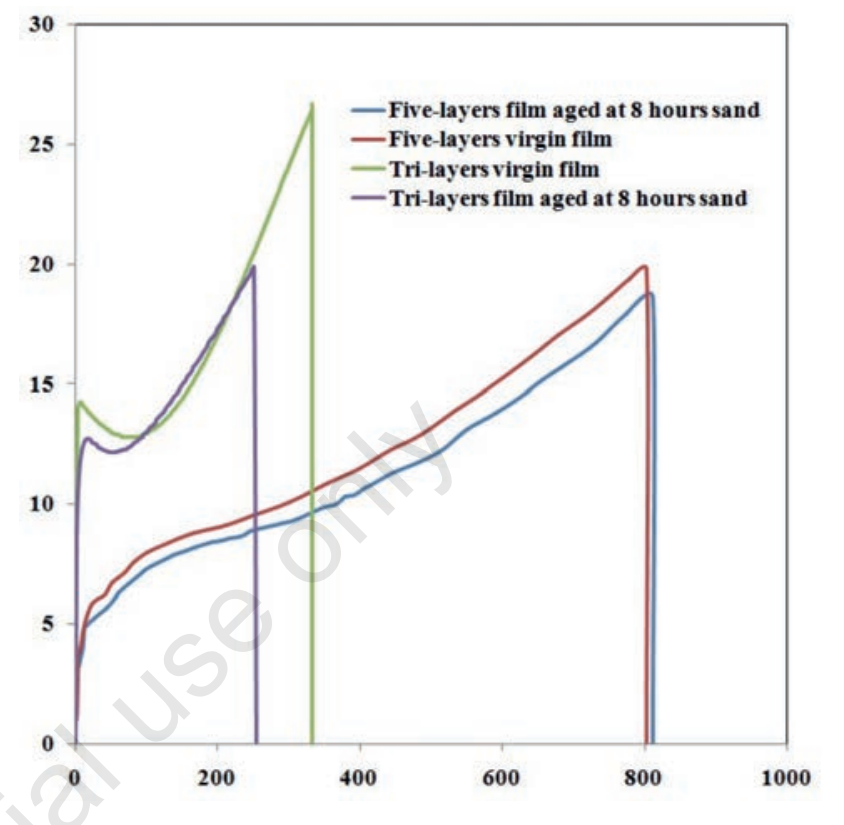

Figure 4. Mechanical behaviour of a five-layer and tri-layer film virgin and aged during $8 \mathrm{~h}$ by a sand-wind at $40^{\circ} \mathrm{C}$.

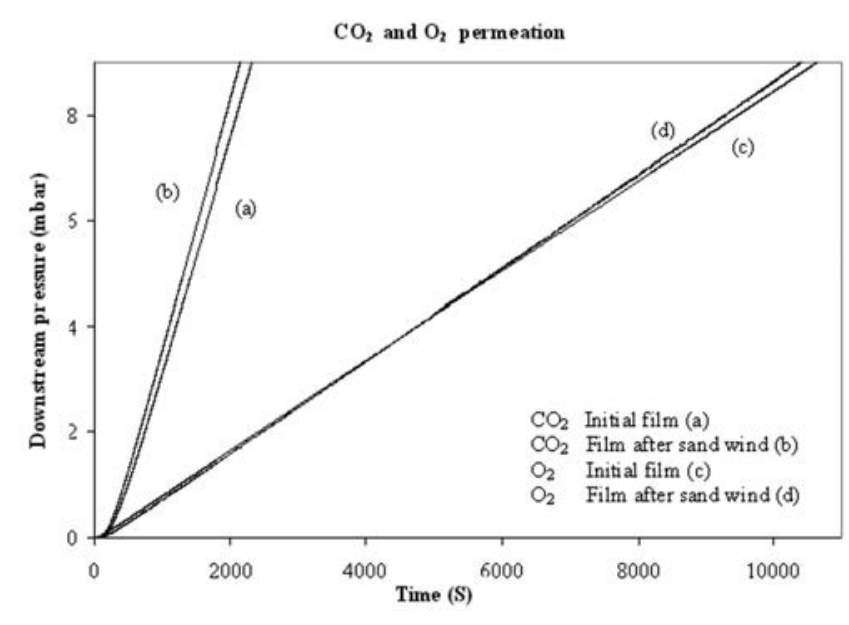

Figure 5. Permeation of oxygen and carbon dioxide at $25^{\circ} \mathrm{C}$ through the five-layer film virgin and aged by a sand-wind at $40^{\circ} \mathrm{C}$ during $8 \mathrm{~h}$. Downstream pressure $\left(\mathrm{p}_{2}\right)$ as a function of time. Sample thickness $=200 \pm 4 \mu \mathrm{m}$. Upstream pressure $=4000 \pm$ mbars.

Table 1. Elastic modulus and deformation at break for mono-, tri- and five-layer virgin films and after sand-wind treatment.

\begin{tabular}{lccccc} 
Type of film & Five-layer initial & Five-layer sand-wind & Tri-layer initial & Tri-layer sand-wind & Mono-layer initial \\
Elastic modulus (MPa) & 0.64 & 0.78 & 0.77 & 0.88 & 0.31 \\
Deformation at break (\%) & 840 & 820 & 420 & 410 & 260 \\
\hline
\end{tabular}


five-layer films. Usually, for a monolayer dense polymer film, the time-lag curve $\left[\mathrm{p}_{2}=\mathrm{f}(\mathrm{t})\right]$ allows to calculate the permeability coefficient $\mathrm{P}$ of the polymer to the gas tested from the slope of the linear part by using (Crank and Park, 1968; Dehbi et al., 2012b):

$$
\mathrm{P}=\frac{\mathrm{L}}{\mathrm{A} \mathrm{p}_{1}} \frac{\mathrm{V}}{\mathrm{p}_{0}} \frac{\mathrm{T}_{0}}{\mathrm{~T}_{\mathrm{m}}} \frac{\mathrm{dp}_{2}}{\mathrm{dt}}
$$

where:

$\mathrm{L}$ is the thickness of the film (mm);

A the effective film area $\left(\mathrm{mm}^{2}\right)$;

$\mathrm{V}$ the calibrated downstream volume $\left(\mathrm{m}^{3}\right)$;

$\mathrm{p}_{1}$ and $\mathrm{p}_{0}$ are the upstream and standard (1 Atm.) pressures respectively;

$\mathrm{T}_{\mathrm{m}}$ and $\mathrm{T}_{0}$ are the measurement and standard $\left(273.13 \mathrm{~K}=0^{\circ} \mathrm{C}\right)$ temperatures respectively;

$\mathrm{dp}_{2} / \mathrm{dt}$ the slope of the downstream pressure with respect to time stationary straight line.

The intercept of the extrapolated stationary straight line with the time axis is the time-lag $t_{\mathrm{L}}$ which is related to the diffusion coefficient $D$ of the gas in the polymer which is given by:

$$
\mathrm{D}=\mathrm{L}^{2} / 6 \mathrm{t}_{\mathrm{L}}
$$

While the solubility coefficient $\mathrm{S}$ of the gas in the polymer is calculated from the ratio:

$\mathrm{S}=\mathrm{P} / \mathrm{D}$

$\mathrm{D}, \mathrm{S}$ and $\mathrm{P}$ are intrinsic properties of a polymer material. In the present case the cover film tested is made of five layers, so that the overall resistance $\mathrm{L} / \mathrm{P}_{\mathrm{m}}$ of the film to gas permeation is the sum of the resistances of each layer, as for electric resistances in series, according to the following equation (Almanza et al., 2005):

$$
\frac{\mathrm{L}}{\mathrm{P}_{\mathrm{m}}}=\sum \frac{\mathrm{L}_{\mathrm{i}}}{\mathrm{P}_{\mathrm{i}}}
$$

where $\mathrm{L}_{\text {and }} \mathrm{L}_{\mathrm{i}}$ are the film and $\mathrm{i}^{\text {th }}$ layer thicknesses respectively, $\mathrm{P}_{\mathrm{m}}$ and $\mathrm{Pi}$ are the mean and $\mathrm{i}^{\text {th }}$ layer permeability coefficients respectively and $\mathrm{L}_{i}$ and $\mathrm{P}_{\mathrm{i}}$ being unknown parameters in the present study. So, by using Equations 3 and 4, the time-lag method allows us to determine the values of the mean and apparent parameters: the overall permeability coefficient Pm of the five-layer film and a mean apparent diffusion coefficient $\mathrm{D}_{\mathrm{m}}$.
The computed values are shown in Table 2. First, it can be noticed that the five-layer film is about five to six times more permeable to carbon dioxide than to oxygen $\left(5.3<\mathrm{P}_{\mathrm{mCO} 2} / \mathrm{P}_{\mathrm{mO} 2}<5.9\right)$ while the carbon dioxide and oxygen apparent diffusion coefficients are of the same order of magnitude. Carbon dioxide is in fact much more soluble (about 12 times) than oxygen in this film as it is usual in the case of most of the polymers. The permeability values obtained are comparable to the values usually measured for LDPE films, i.e. 6 to 12 Barrer and 1.5 to 2.1 Barrer, for carbon dioxide and oxygen respectively (Guenachi et al., 2002) or Dow LDPE films (Braudrup and Immergut, 1989).

Secondly, the carbon dioxide permeability of the sand-wind treatment film seems to be slightly higher than that of the initial film. The slope $\mathrm{dp}_{2} / \mathrm{dt}$ is in fact slightly higher for the aged film with regard to the initial film. This could be due to a minimal and not easily measured diminution of the film thickness attributable to the surface abrasion and formation of micro-cracks $\left(\mathrm{P}_{\mathrm{m}}\right.$ has been calculated considering the same thickness $(200 \mathrm{~mm})$ for both films). Owing to the measurement uncertainties, the increase of $\mathrm{P}_{\mathrm{m}}$ is not really convincing.

\section{Conclusions}

The effect of simulation using sand wind for $8 \mathrm{~h}$ at $40^{\circ} \mathrm{C}$, under temperature and temperature/UVA condition for $1000 \mathrm{~h}$ at $40^{\circ} \mathrm{C}$ for a five-layer polymer cover film has been studied by using several physicochemical characterisation methods. The optical analysis show distinctly the deterioration on the surface of the tri-layer then the five layers film after $8 \mathrm{~h}$ of exposure to sand-wind at $40^{\circ} \mathrm{C}$. The FTIR spectra and free surface energy calculated using contact angle method indicated all the three test conditions modified the film surface due to cross-linkage, oxidation and chain scission reactions. In FTIR a band vibration of Si groups appeared after the sand-wind simulation.

The mechanical test showed a slight increase of the elastic modulus and a decrease in the elongation at break after treatment, attributed by the superficial cross-linking occurred on the film. Due to the deterioration of the superficial layers of the material, the gas permeability flow increased slightly through the aged films. Finally we can conclude that the surface properties of the films were more affected by these treatments and the properties of the five-layer film are better when compared to mono- or tri-layer films after exposure. Technical aspects about the performance of these materials during the working life are usually poorly reported and further experimental analysis should be conducted. The limited life of agricultural plastic films would indeed be enhanced

\begin{tabular}{|c|c|c|c|}
\hline Gas/film & $10^{12} \times D_{m}\left(m^{2} s^{-1}\right)$ & $\mathbf{P}_{\mathrm{m}}$ (Barrer)* $^{*}$ & $\mathrm{P}_{\mathrm{CO} 2} / \mathrm{P}_{02}$ \\
\hline $\mathrm{CO}_{2}$ (initial five layer film) & Undetermined & 11.1 & 5.3 \\
\hline $\mathrm{CO}_{2}$ (five layer film, sand-wind) & 26 & 23.7 & 5.9 \\
\hline $\mathrm{O}_{2}$ (initial five layer film) & 27 & 2.1 & - \\
\hline $\mathrm{O}_{2}$ (five layer film, sand wind) & 33 & 4.0 & - \\
\hline $\mathrm{O}_{2}$ (initial LDPE film) $^{\circ}$ & 25 & 2.2 & - \\
\hline $\mathrm{O}_{2}$ (LDPE film, sand wind) ${ }^{\circ}$ & 26 & 2.2 & - \\
\hline
\end{tabular}

Table 2. Mean apparent diffusion coefficient $\left(\mathrm{D}_{\mathrm{m}}\right)$ and overall permeation coefficient $\left(\mathrm{P}_{\mathrm{m}}\right)$ of $\mathrm{O}_{2}$ and $\mathrm{CO}_{2}$ through the five-layer film virgin and aged by a sand-wind at $40^{\circ} \mathrm{C}$ during $8 \mathrm{~h}$.

*1 Barrer $=10^{10} \mathrm{~cm}^{3} \mathrm{STP} \mathrm{cm}^{-2} \mathrm{~s}^{-1} \mathrm{~cm} \mathrm{cmHg}^{-1}$. Uncertainties are estimated to 10\%; ${ }^{\circ}$ for comparison, monolayer LDPE film. Permeability measurements made by using the differential permeation method. 
thanks to new more efficient customised formulations, performed with the support of suitable equations, able to predict their useful lifetime considering the meteorological characteristics of the area where this material will be exposed and the operative conditions (contact with pesticides/agrochemicals, external pollution, contact with structural frames, etc.).

\section{References}

Allen N.S., Adge M., Houldsworth D., Rahman A., Catalina F., Fontan E., Escalona A.M., Sibon F.F. 2000. Ageing and spectroscopic properties of polyethylenes: comparison with metallocene polymer. Polym. Degrad. Stab. 67:57-67.

Almanza O., Rodríguez-Pérez M.A., Chernev B., de Saja J.A., Zipper P. 2005. Comparative study of the lamellar structure of polyethylene foam. Eur. Polym. J. 41:599-608.

Braudrup J., Immergut E.H. 1989. Polymer handbook, section A, chapter 6. (3rd Ed.). J. Wiley \& Sons, New York, NY, USA.

Briassoulis D. 2006. Mechanical behaviour of biodegradable agricultural films under real field conditions. Polym. Degrad. Stab. 9:1256-72.

Briassoulis D. 2007. Analysis of the mechanical and degradation performances of optimised agricultural biodegradable films. Polym. Degrad. Stab. 92:1115-32.

Crank J., Park J.S. 1968. Method of measurement in diffusion in polymers. Academic Press, London and New York, Chapter 1, pp 1-39.

Dehbi A., Djakhdane K., Mourad A.H.I. 2012a. Impact of degradation of polyethylene films under simulated climatic conditions on their mechanical behavior and thermal stability and lifetime. Am. Soc. Mech. Eng. Pres. Ves. Pip. Div. Parts A and B 6:131-5.

Dehbi A., Mourad A.H.I. 2011. Durability of mono-layer versus tri-layers LDPE films used as greenhouse cover: Comparative study. Arabian J. Chem. [epub ahead of print].

Dehbi A., Mourad A.H.I., Bouaza A. 2012b. Degradation assessment of LDPE multilayer films used as a greenhouse cover: natural and artificial aging impacts. J. Appl. Polym. Sci. 124:2702-16.

Dehbi A., Mourad H.I., Djakhdane K., Hilal-Anaqbi A. 2015. Degradation of thermo-mechanical performance and lifetime estimation of multilayer greenhouse polyethylene films under simulated climatic conditions. Polym. Eng. Sci. 55:287-98.

Dehbi A., Youssef B., Chappey C., Mourad A.-H.I., Picuno P., Statuto D. 2017. Multilayers polyethylene film for crop protection in harsh climatic conditions. Adv. Mater. Sci. Engine. 2017:4205862.

Dilara A., Briassoulis D. 1998. Standard testing methods for mechanical properties and degradation of low density polyethylene (LDPE) films used as greenhouse covering materials: a critical evaluation. Polym. Test 17:549-85.

Fuina S., Marano G.C., Puglisi G., De Tommasi D., ScarasciaMugnozza G. 2016. Thermo-mechanical response of rigid plastic laminates for greenhouse covering. J. Agric. Engine. 47:157-63.

Guenachi K., Hamou A., Hassini N., Saiter J-M., Marais S., Beucher E. 2002. Influence of sand winds on the durability of polyethylene greenhouse aged under sub-saharan climatic conditions. Mat. Res. Inovant. 6:174-8.

Gulmine J.V., Janissek P.R., Heise H.M., Akcelrud L. 2003. Degradation profile of polyethylene after artificial accelerated weathering. Polym. Degrad. Stab 79:385-97.

Joly C., Le Cerf D., Chappey C., Langevin D., Muller G. 1999. Residual solvent effect on the permeation properties of fluorinated polyimide films. Separat. Purif. Technol. 16:47-54.

Mourad A.-H.I. 2010. Thermo-mechanical characteristics of thermally aged polyethylene/polypropylene blends. Mater. Des. 31:918-29.

Mourad A-H.I., Dehbi A. 2014. On use of tri-layer low density polyethylene greenhouse cover as substitute for monolayer cover. Plastics Rubber Compos. Macromol. Engine. 43:111-21.

Owens D.K., Went R.C. 1969. Estimation of the surface free energy of polymers. J. Appl. Polym. Sci 13:1741-47.

Picuno P. 2014. Innovative material and improved technical design for a sustainable exploitation of agricultural plastic film. Polym. Plast. Technol. Eng. 53:1000-11.

Picuno P., Scarascia-Mugnozza G., Sica C., Dimitrijevic A., Laviano R. 2012. Experimental tests and technical characteristics of regenerated films from agricultural plastics. Polym. Degrad. Stabil. 97:1654-61.

Schettini E., De Salvador F.R., Scarascia-Mugnozza G., Vox G. 2011. Radiometric properties of photoselective and photoluminescent greenhouse plastic films and their effects on peach and cherry tree growth. J. Hortic. Sci. Biotech. 86:79-83.

Statuto D., Cillis G., Picuno P. 2016. Analysis of the effect of agricultural land use change on rural environment and landscape through historical cartography and GIS tools. J. Agricult. Engine. 47:28-39.

Statuto D., Picuno P. 2017. Micro-Climatic effect of shading plastic nets for crop protection in Mediterranean areas. In: 45th Symposium "Actual Tasks on Agricultural Engineering", Opatija, Croatia.

Statuto D., Tortora A., Picuno P. 2013. A GIS approach for the quantification of forest and agricultural biomass in the Basilicata region. J. Agricult. Engine. 44(sI):627-31.

Youssef B., Dehbi A., Hamouand A., Saiter J.M. 2008. Natural ageing of tri layer polyethylene film: evolution of life time in north Africa region. Polymer Design. 29:2017-22. 